\title{
Yangtse River sediments and erosion rates from source to sink traced with cosmogenic ${ }^{10} \mathrm{Be}$ : Sediments from major rivers
}

\author{
John Chappell $^{\mathrm{a}, *}$, Hongbo Zheng ${ }^{\mathrm{b}}$, Keith Fifield ${ }^{\mathrm{c}}$ \\ ${ }^{a}$ Research School of Earth Sciences, Australian National University, Canberra, Australia \\ ${ }^{\mathrm{b}}$ School of Ocean and Earth Science, Tongji University, Shanghai, China \\ ${ }^{c}$ Research School of Physical Sciences and Engineering, Australian National University, Canberra, Australia
}

Received 7 February 2005; accepted 26 June 2006

\begin{abstract}
Estimates of regional erosion and sediment mixing from different sources in the Yangtse River system are presented, based on sand samples collected from major tributaries and the trunk stream, at 23 sites between western Sichuan and the Yangtse Delta. Mixing is estimated from concentrations of $\mathrm{Mg}, \mathrm{Ca}, \mathrm{Sr}, \mathrm{Ti}, \mathrm{Mn}$ and $\mathrm{Fe}$, which are substantially higher in sand from major tributaries in the western Yangtse River catchment than from tributaries in the eastern catchment. Intermediate concentrations occur in sand from the Yangtse Delta, both for modern samples from the surface and for early Holocene samples from drill holes. Mixing ratios indicate that $35 \pm 5 \%$ of sand in the delta came from eastern sources. A similar result was obtained using cosmogenic ${ }^{10} \mathrm{Be}$ in quartz grains as a tracer of mixing. Regional erosion rate estimated from ${ }^{10} \mathrm{Be}$ in sand grains from high mountain catchments of the western Yangtse River are mostly similar to rates based on sediment gauging but are sometimes higher, and range to over $700 \mathrm{~m} \mathrm{Ma}^{-1}$, while ${ }^{10} \mathrm{Be}$ measured at upper Yangtse River tributaries on the northeast Tibetan plateau gave rates of $20-30 \mathrm{~m} \mathrm{Ma}^{-1}$. For the eastern catchments, ${ }^{10} \mathrm{Be}$ measurements from quartz sand and sediment gauging both gave rates of $30-70 \mathrm{~m} \mathrm{Ma}^{-1}$. Eroding at this rate, the eastern catchments could not supply more than $20 \%$ of the sediment in the delta, in contrast with $35 \%$ estimated from geochemical fingerprints. The relative input from eastern sources may have been higher in Late Pleistocene times, under a different climatic regime, and reworking of Pleistocene deposits may still be in progress.
\end{abstract}

(C) 2006 Published by Elsevier B.V.

Keywords: Yangtse River; Erosion; Beryllium-10; Sediments; Source-to-sink

\section{Introduction}

Erosion, loss of soil and river degradation through the impacts of human activities are familiar problems. Although methods for improving the situation may seem obvious, such as integrated catchment management and afforestation, the real characteristics of such problems may not be accurately known, because rates of

\footnotetext{
* Corresponding author. Tel.: +61 261258113.

E-mail address: jchappell@anu.edu.au (J. Chappell).
}

erosion and sediment movements prior to human impacts often are poorly known. With the aim of establishing longer-term average rates of erosion and sedimentation, we report the findings of the first stage of a new project in which we trace sediments and estimate catchment erosion rates through the Yangtse River system, using chemical fingerprints of river sand and cosmogenic ${ }^{10} \mathrm{Be}$ in quartz grains. The Yangtse River rises in the northeast Tibetan Plateau and descends through ranges of high mountains, before passing eastwards across China, collecting water and sediment 
from a series of tributary rivers as it goes, before passing through the Yangtse Delta into the East China Sea. Human population throughout the river basin is large, and the region has a long, complex history of intensive agricultural land-use, river manipulation and land reclamation - all of which have altered and concealed the natural erosional and sedimentary processes (Osborne, 1998; Vermeer, 1998; Elvin, 2004).

Our objectives are to evaluate large-scale sediment sources and sinks in the Yangtse River system, and to estimate long-term rates of sediment supply from major sources, for comparison with recent river gauge data. The project began in 2001 with collection of reconnaissance samples, which are the basis for this paper. Studies of erosion and sediment yields from mountain slopes to small- and intermediate-scale catchments are currently under way, in parallel with drill-core studies of sedimentary sequences in terrestrial and offshore basins. We report initial findings from sediments collected from the Yangtse River and its major tributaries, between western Sichuan and the delta, supplemented by gaugings of river discharge and sediment flux reported in the Chinese scientific literature.

Geochemical methods are used to examine the mixing of sediments from different source regions, based on conventional elemental analyses, together with cosmogenic ${ }^{10} \mathrm{Be}$ in quartz sand grains $\left({ }^{10} \mathrm{Be}_{\mathrm{s}}\right) \cdot{ }^{10} \mathrm{Be}$ is produced in surface rocks by interactions with cosmic rays, and varies with altitude and rate of erosion of the rock surface (Lal, 1991). Because altitude and erosion rate are largely uncorrelated with lithology, it was anticipated that ${ }^{10} \mathrm{Be}_{\mathrm{s}}$ would provide an independent indicator of provenance of sediments at different localities in the Yangtse River system. Using the dependence of cosmogenic ${ }^{10} \mathrm{Be}_{\mathrm{s}}$ on erosion rate (Lal, 1991; Gosse and Phillips, 2001), we also aimed to estimate erosion rates in sediment source regions.

\section{The Yangtse River basin}

The Yangtse River is one of the world's great rivers. With a catchment area of $1.8 \times 10^{6} \mathrm{~km}^{2}$, its average discharge $\left(\sim 30,000 \mathrm{~m}^{2} \mathrm{~s}^{-1}\right)$ exceeds that of the Mississippi and is comparable with the GangesBrahmaputra. Fig. 1 shows a map of the Yangtse River catchment, which can be divided into five broad physiographic provinces (see inset map, Fig. 1). From west to east, these include the northeast Tibet Plateau, the high mountains of the Longmen Shan and associated ranges, the Sichuan Basin, mixed mountain and basin terrains, and eastern lowlands. The upper Yangtse River, known as the Jinsha Jiang ("jiang" means "river"), descends from the plateau through the mountains and is joined in western Sichuan by several major tributaries that pass through very deep valleys and gorges in the Longmen Shan, including the Yalong Jiang, the Dadu He ("he" also means "river"), and the Min Jiang. Further downstream, the Yangtse River is joined by the Jialing Jiang, which drains much of the Sichuan Basin, and the Wu Jiang, before passing through the Three Gorges to the eastern lowlands, where it is joined by major tributaries, including the Han Shui from the mountainous northwest, and the Yuan Jiang, Xiang Jiang and Gan Jiang from the south. Several of these rivers are separated from the Yangtse River through lakes and wetlands (e.g. Dongting Lake and Poyang Lake: Fig. 1), which trap sediment from the tributaries. The Yangtse River enters the sea through a very large, tide-dominated delta, which has prograded more than $200 \mathrm{~km}$ seawards in the last 7000 years (Li et al., 2000; Hori et al., 2001). Mixing of salt and fresh water is confined to the delta but, owing to the low gradient through the eastern lowlands, tidal currents penetrate up to $290 \mathrm{~km}$ upstream (Shen, 1998).

Meteorologically, the Yangtse River catchment is dominated by seasonal alternation between the warm, wet summer monsoon, and the cold, dry winter monsoon. Annual precipitation tends to decrease westward from about $1000 \mathrm{~mm}$ in the eastern lowlands to about $700 \mathrm{~mm}$ in the Sichuan Basin, but rises to over $1700 \mathrm{~mm}$ on the eastern flanks of the central Longmen Shan. West of the Longmen Shan, precipitation decreases across the plateau, from about $600 \mathrm{~mm}$ in the middle reaches of the Yalong Jiang to about $400 \mathrm{~mm}$ at the head of the Jinsha Jiang. Summer temperatures tend to be warm throughout the Yangtse River catchment, particularly in the eastern lowlands where the average for July can exceed $30^{\circ} \mathrm{C}$. Winter is mild to cool in the eastern lowlands and Sichuan Basin, whereas winter on the plateau is very cold and dry, with sub-zero temperatures. The mountains of the Longmen Shan carry permanent snow above 5100-5300 m

Tectonically, the eastern lowlands and western source regions are very different: the western catchments, dominated by the Longmen Shan, are subject to ongoing uplift, whereas eastern China is comparatively stable. The Longmen Shan and neighbouring ranges rise to over $6000 \mathrm{~m}$ and, in their passage through the mountains, the western rivers receive large inputs of sediment from landslides cascading off steep unstable slopes that rise 1500-2500 $\mathrm{m}$ above the local valleys. In contrast, the eastern lowlands are a complex of floodplains and lacustrine basins, rimmed by relatively low mountains. The western reaches and Sichuan Basin are fluvially decoupled from the eastern lowland by the 


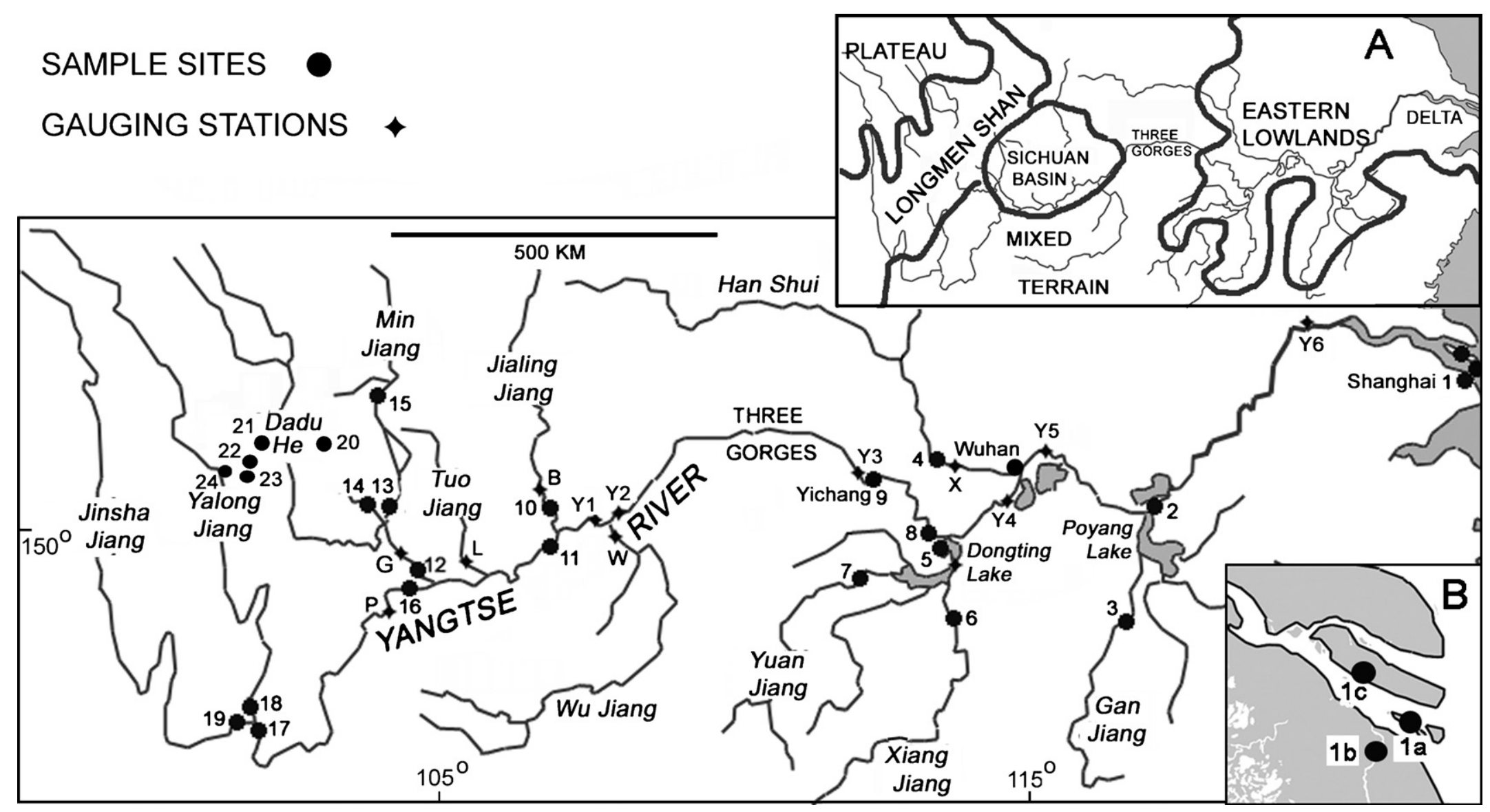

Fig. 1. Map of Yangtse River catchment, showing principal rivers (e.g. Min Jiang, Dadu He, Han Shui). River discharge and sediment flux data listed in Table 1 are from gauging stations situated at letter-labelled symbols. Sampling sites are shown as numbered solid circles and are listed in Table 2. Inset maps: (A) major physiographic provinces (see text); (B) delta drill-core locations. 
Three Gorges bedrock reach and are isolated from the effects of Quaternary sea level changes. In the eastern lowlands and delta, episodes of river incision during glacial-age low-stands alternated with aggradation during periods of rising and high sea level.

Sediment inputs to the Yangtse River system are likely to have varied with Quaternary climate changes. Although much field evidence in the upper Yangtse River catchment awaits systematic description, glacial and periglacial processes are active today above $\sim 5200 \mathrm{~m}$ and, to draw a parallel with Tibet (Derbyshire et al., 1991), periglacial processes were considerably more extensive during Quaternary glacial periods. Summer monsoonal precipitation in China decreased markedly in glacial phases and the winter monsoon was drier than today (Xiao et al., 1999), temperatures were at least $5^{\circ} \mathrm{C}$ colder and, to judge from pollen data from sites across China (Sun et al., 1997; Sun et al., 2000), the area of forest in the western Yangtse River catchment was much reduced, and was more xeric in the eastern Yangtse River lowlands (Yi et al., 2003). With reduced vegetation and enhanced periglaciation, sediment fluxes from mountain slopes may have been higher than in the warm, wet interglacials. We note that erosion does not necessarily increase monotonically with rainfall, and tends to increase if vegetation shifts from forest to grass- or shrubland (Selby, 1993); instability caused by a shift to cold climate also tends to accelerate erosion (Zhang et al., 2001). Increased sediment flux and reduced river discharge would lead to valley aggradation, evidence for which is seen in alluvial terraces in the headwaters and upper reaches of the Yangtse River and its major western tributaries.

Sediment inputs to the Yangtse River almost certainly increased over the last millennium and perhaps over a longer period, as a result of forest clearing and intensified use of hill country (Elvin, 2004). Human impacts have been severe in parts of China, particularly the loess plateau, where accelerated erosion in the last 1000 years has caused a tenfold increase of sediment in the Yellow River (Xue, 1993). Erosion and soil-loss in the Yangtse River catchment, although less dramatic, appears to have been widespread and serious during periods when hills and forests were rapidly exploited in the 18th and 19th centuries (Osborne, 1998; Vermeer, 1998), and again in the mid-20th century following the "Great Leap Forward" in 1958. However, sediment from freshly eroding hills historically has invaded lowland farms (Elvin, 2004), and to guess the proportion flushed to the rivers is difficult. Relict dykes and ancient shorelines indicate accelerated coastal progradation of the Yangtse River delta in the last millennium (Li et al., 2000) and suggest increased sediment input, although intensified methods of coastal land reclamation may have been a contributing factor (Elvin and Su, 1998).

\section{Yangtse River sediment fluxes, sources and sinks}

\subsection{Fluxes}

Observations of water discharge and suspended sediment have been reported for a number of gauging stations in the Yangtse River system (Lin, 1989; Wang et al., 1997). Annual sediment fluxes recorded at major stations (locations, Fig. 1) are summarised in Table 1. Fig. 2 presents a graph of cumulative totals of water and sediment downriver from western Sichuan to the delta, and shows that discharge increases downstream and doubles as the river passes through the eastern lowlands. Sediment flux also increases through the western reaches but decreases in the eastern lowlands, although the eastern tributaries carry substantial sediment loads. The eastern lowlands clearly are a sediment sink. If the fluxes given in Table 1 were to persist, about $60 \mathrm{~km}^{3}$ of sediment would accumulate in 1000 years, in the lowlands between Yichang and Wuhan.

\subsection{Sediment sources}

Gauge data indicate that most of the Yangtse River sediment originates upstream of the Three Gorges,

Table 1

Annual sediment discharge recorded at gauged sites on the Yangtse River system

\begin{tabular}{|c|c|c|}
\hline $\begin{array}{l}\text { River and location } \\
\text { (see Fig. 1) }\end{array}$ & $\begin{array}{l}\text { Sediment } \\
\left(\times 10^{6} \mathrm{t} \mathrm{yr}^{-1}\right)\end{array}$ & Data sources \\
\hline Jinsha River at Pinshan (P) & 240 & $\begin{array}{l}\text { Lin, 1989; Wang et al., } \\
1997\end{array}$ \\
\hline Min River at Gaoyang (G) & 48 & Lin, 1989 \\
\hline Tuo River near Luzhou (L) & 12 & Lin, 1989 \\
\hline Jialing River at Beipei (B) & 70 & Lin, p.c. ${ }^{\mathrm{a}}$ \\
\hline Yangtse at Cuantan (Y1) & 410 & Wang et al., 1997 \\
\hline Wu River at Wuleng (W) & 32 & Lin, 1989 \\
\hline Yangtse near Wu Jiang (Y2) & 488 & Sum to this point $\mathrm{t}^{\mathrm{b}}$ \\
\hline Yangtse at Yichang (Y3) & 520 & $\begin{array}{l}\text { Lin, 1989; Wang et al., } \\
1997\end{array}$ \\
\hline Dongting Lake, inflow & 48 & Lin, 1989 \\
\hline Yangtse at Luoshan (Y4) & 430 & $\begin{array}{l}\text { Lin, 1989; Wang et al., } \\
1997\end{array}$ \\
\hline Han Shui at Xiantao (X) & 57 & Lin, 1989 \\
\hline Yangtse below Wuhan (Y5) & 430 & $\begin{array}{l}\text { Lin, 1989; Wang et al., } \\
1997\end{array}$ \\
\hline Yangtse at Datong (Y6) & 480 & $\begin{array}{l}\text { Lin, 1989; Wang et al., } \\
1997\end{array}$ \\
\hline
\end{tabular}

Letters in parentheses refer to locations shown in Fig. 1.

a Professor Lin Chengkun, personal communication.

b Total of Lin (1989) figures from Jinsha Jiang to Wu Jiang. 


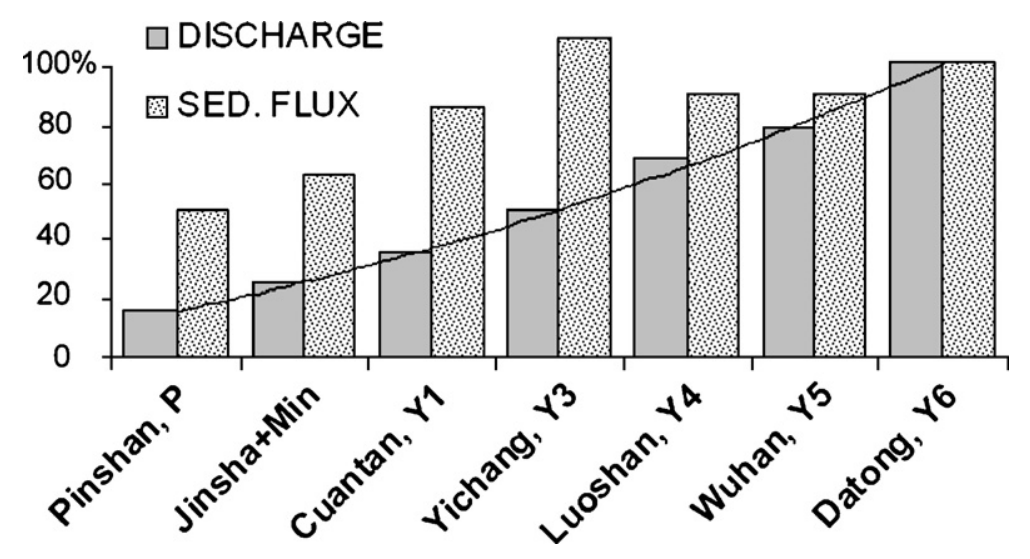

Fig. 2. Downstream trends of Yangtse River mean discharge and annual sediment flux, as percentage of total upstream of delta (Datong gauge; location Y6, Fig. 1). Water discharge increases progressively downstream; sediment flux diminishes when Yangtse River enters the eastern lowlands below Yichang. Letters attached to place-names are keys to gauging stations identified in Fig. 1 and Table 1.

dominantly from the high regions of western Sichuan where the major sources are the mountain catchments of the Jinsha Jiang, Yalong Jiang, and Min-Dadu River systems, in the Longmen Shan (Fig. 1). With summits above $6000 \mathrm{~m}$ above sea level (the highest, Gonga Shan, is $7500 \mathrm{~m}$ ), these catchments include major tracts of high mountains cut by gorges and deep, steep-sided valleys, together with high-altitude rolling plateau, 3500-4500 $\mathrm{m}$ above sea level. West of the Longmen Shan, the proportion of plateau increases and precipitation decreases. The rivers carry coarse bedload together with sand in their mountain reaches, where valley walls typically rise $1500-2500 \mathrm{~m}$ above river level. Landslides dominate mass-wasting in the steepsided valleys and the rivers often cut equally into both bedrock and coarse diamictites, tens of metres thick. In contrast, rolling hills and tablelands of the plateau carry a thin stony soil mantle over bedrock, with localised areas of gully erosion. Both gullying on the plateau and landslides in the valleys are said by local people to have increased since widespread forest clearing occurred in the late 1950s. Mass movement associated with periglacial solifluction is apparent on the plateau above $4500 \mathrm{~m}$, increasing towards the snowline at $\sim 5300 \mathrm{~m}$.

The composition of Yangtse River sand reflects regional lithologic variations. At the broadest scale, sand from the western reaches is dark and lithic in appearance whereas sand from the eastern catchments is more quartzo-felspathic. Variations in the proportion of quartz-rich facies are of particular interest, because quartz grains in river sand comprise the material used for ${ }^{10} \mathrm{Be}$ determinations, which are the basis for estimating regional erosion rates discussed later in this paper. Such variation became apparent when, guided by $1: 1,100$, 000-scale geologic maps (Ministry of Geology, 1991), we explored some of the western catchments in July 2004 and found that the proportion of quartz particles in river sediment is relatively high in the metamorphic terrain of the Longmen Shan, is lower in TriassicJurassic shale terrain further west, and is negligible in the limestone headwaters of the Min Jiang.

\subsection{Sediment sinks}

Since the last glacial low-stand, 20,000 years ago, sedimentation in the eastern lowlands must have been dominated by deposition of transgressive and high-stand deposits, initiated by post-glacial sea level rise. Sedimentation in the lowlands continues today. Fig. 2 shows that the Yangtse River increases in discharge but loses sediment as it passes through the lacustrine lowlands of the eastern Yangtse River, where networks of lakes and wetlands adjoining the river act as sediment sinks - as illustrated by Dongting Lake, which separates the Yangtse River from large tributary rivers that join the lake through skeins of channels and deltas (Fig. 3).

Although the net effect is trapping, sediment both enters and leaves the sinks, and is remobilised by migrating meanders of the Yangtse River. It is difficult to quantify long-term sediment exchange between the Yangtse River and the lacustrine and floodplain sediment traps, based on gauging data. Historical records show that lakes and wetlands in the Yangtse River lowlands are infilling with sediment, but the contribution of catchment erosion has been masked by the effects of both land reclamation and river manipulation: for example, sedimentation and reclamation in Dongting Lake accelerated in the late 17 th century, when closure of outlets 


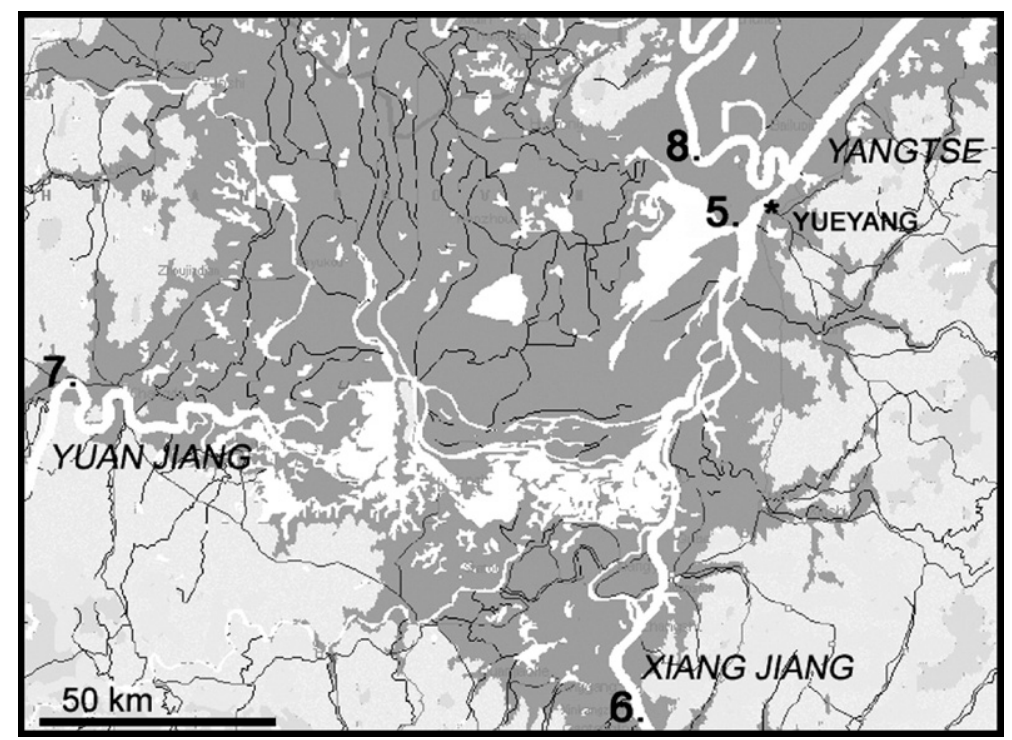

Fig. 3. Sediment sink region surrounding Dongting Lake in the Yangtse River lowlands. River channels and lakes are shown in white, former lakes and wetland in dark gray. Black lines are canals and minor channels. Numbers indicate sampling sites marked in Fig. 1.

along the northern bank of the Yangtse River led to rapid increases in the flux of water and sediment into the lake itself (Vermeer, 1998). Our study is a step towards evaluating the extent of sediment mixing and trapping, in post-glacial and historical timeframes.

\section{Methods}

\subsection{Sites and samples}

This study of large-scale sediment sources and sinks in the Yangtse River system began in May 2001 with collection of bulk samples of river sand from the delta, trunk stream and major tributaries of the Yangtse River. Channel deposits of types that tend to be preserved stratigraphically, such as mid-channel bars, lateral bars and point bars, were preferred targets but sampling was constrained by several factors. The Yangtse River and its tributaries are very large and, as we often experienced high river levels, a number of samples were taken from river dredges or from stockpiles of dredged sand. Aiming to get representative material, our riverbed samples were mixtures of sub-samples taken from several points around each sampling site, whereas dredge and stockpile samples were assumed to have been well-mixed during dredging operations. Samples were also taken from radiocarbon-dated levels in Holocene drill-cores from the Yangtse River delta, in order to discover whether we could detect changes in sediment inputs from different sources during the rise of Chinese civilisation. The samples came from a set of cores taken in studies of Holocene progradation of the Yangtse Delta, reported by Li et al. (2000) and Hori et al. (2001), and were made available by Professor Li Congxian at Tongji University, Shanghai.

Site locations are shown in Fig. 1, and Table 2 lists the sample sites, together with ${ }^{10} \mathrm{Be}$ measurements referred to later, as well as radiocarbon ages of drill core samples. Sampling was extended in July 2004 into selected headwaters of the Yangtse River in the Longmen Shan and adjacent plateau, where samples were collected from exposed bedrock surfaces and 1 st to 3 rd order streams, as well as from larger rivers. Analyses of the 2004 samples have not been completed and the results will be described in detail in a later publication, but measurements of cosmogenic ${ }^{10} \mathrm{Be}$ for a small subset of outcrop and stream sediment samples from the plateau and mountain valleys are included here (Table 2, sites 20-24).

Considering the size of the Yangtse River system and the relatively small number of samples (23 sites; 33 samples), this is only a reconnaissance study. Some rivers were sampled at several sites but others at only one locality. Two large tributaries, the Wu Jiang and Dadu $\mathrm{He}$, were not sampled, but two tributaries of the Dadu He were sampled and its input to the Min Jiang is bracketed by samples from upstream and downstream of the junction. Reassuringly, geochemical results from rivers sampled at more than one site are consistent with one another.

\subsection{Analyses}

Geochemical analyses were made of fine sand $(100-200 \mu \mathrm{m})$ sieved from each bulk sample. Care 
Table 2

Sample sources, keyed by numbers to locations shown on Fig. 1

\begin{tabular}{|c|c|c|c|c|c|}
\hline Site no. (Fig. 1) & Lab code & Site name and type & Element analyses & ${ }^{10} \mathrm{Be}\left(\times 10^{6}\right.$ atoms $\left.\mathrm{g}^{-1}\right)$ & ${ }^{10} \mathrm{Be}$ error \\
\hline \multicolumn{6}{|l|}{$\overline{\text { Delta sites }}$} \\
\hline $1 \mathrm{a}$ & Y01-01 & Tidal flat, Changxing island & $\mathrm{X}$ & $\mathrm{nr}^{*}$ & \\
\hline 1a & Y02-01 & Delta dredge, Changxing Is & $\mathrm{X}$ & 0.27 & 0.014 \\
\hline $1 b$ & Y03-01 & Delta, Shanghai core $5830 \mathrm{BP}$ & $\mathrm{X}$ & * & \\
\hline $1 \mathrm{c}$ & Y26-01 & Delta, Chongming core 2140 BP & $\mathrm{X}$ & * & \\
\hline $1 \mathrm{c}$ & Y27-01 & Delta, Chongming core $10000 \mathrm{BP}$ & $\mathrm{X}$ & 0.30 & 0.028 \\
\hline $1 \mathrm{c}$ & Y25-01 & Delta, Chongming core $11140 \mathrm{BP}$ & $\mathrm{X}$ & 0.33 & 0.017 \\
\hline \multicolumn{6}{|c|}{ Eastern catchments } \\
\hline 2 & Y24-01 & Yangtse dredge, Penzhue & $\mathrm{X}$ & 0.12 & 0.009 \\
\hline 3 & Y23-01 & Gan Jiang dredge, Nanchang & $\mathrm{X}$ & 0.14 & 0.015 \\
\hline 4 & Y18-01 & Han Shui lower bank, Xian Tao & $\mathrm{X}$ & 0.10 & 0.006 \\
\hline 5 & Y21-01 & Dongting Lake dredge, Yueyang & $\mathrm{X}$ & 0.10 & 0.006 \\
\hline 6 & Y20-01 & Xiang Jiang dredge, Changsha & $\mathrm{X}$ & 0.12 & 0.007 \\
\hline 7 & Y19-01 & Yuan Jiang dredge, Changde & $\mathrm{X}$ & 0.16 & 0.009 \\
\hline 8 & Y22-01 & Yangtse bank, above Dongting & $\mathrm{X}$ & 0.25 & 0.012 \\
\hline \multicolumn{6}{|c|}{ Western catchments } \\
\hline 9 & Y13-01 & Yangtse dredge, Yichang & $\mathrm{X}$ & $\mathrm{nr}^{*}$ & \\
\hline 10 & Y16A-01 & Jialing Jiang dredge, Qongqing & $\mathrm{X}$ & 0.20 & 0.016 \\
\hline 10 & Y16B-01 & ditto, second dredge & $\mathrm{X}$ & 0.14 & 0.009 \\
\hline 11 & Y15-01 & Yangtse dredge, Qongching & $\mathrm{X}$ & 0.44 & 0.019 \\
\hline 12 & Y13-01 & Min Jiang point bar, Yibin & $\mathrm{X}$ & 0.07 & 0.006 \\
\hline 13 & Y07-01 & Min Jiang dredge, Leshan & $\mathrm{X}$ & 0.05 & 0.004 \\
\hline 14 & Y05-01 & Qingyi Jiang mid-channel bar & $\mathrm{X}$ & 0.04 & 0.003 \\
\hline 15 & Y04-01 & Min Jiang point bar, Dujiangyan & $\mathrm{X}$ & 0.06 & 0.008 \\
\hline 16 & Y14-01 & Jinsha dredge, Yibin & $\mathrm{X}$ & 0.58 & 0.030 \\
\hline 17 & Y10-01 & Jinsha lateral bar below Yalong & $\mathrm{X}$ & 0.45 & 0.040 \\
\hline 18 & Y08-01 & Yalong lateral bar & $\mathrm{X}$ & 0.13 & 0.016 \\
\hline 19 & Y11-01 & Jinsha pointbar 1 , Panzhihua & $\mathrm{X}$ & 1.14 & 0.047 \\
\hline 19 & Y12-01 & Jinsha pointbar 2, Panzhihua & $\mathrm{X}$ & 1.05 & 0.036 \\
\hline 20 & $\mathrm{CN} 23,25$ & Upper Xiao Jin Chuan, ave. 4000 m & * & 0.06 & 0.015 \\
\hline 21 & $\mathrm{CN} 21$ & Upper Danba stream, ave. $4400 \mathrm{~m}$ & * & 0.05 & 0.016 \\
\hline 22 & $\mathrm{CN} 07,08$ & Upper Tagong hills, $4000 \mathrm{~m}$ & $*$ & 1.38 & 0.07 \\
\hline 23 & $\mathrm{CN} 16,19$ & Gao Er Si Pass, $4400 \mathrm{~m}$ & * & 1.91 & 0.08 \\
\hline
\end{tabular}

Radiocarbon ages are listed for delta drill core samples (Y03-01 and Y25, 26, 27-01).

Elemental analyses were made on fine sand extracted from samples labelled X; results are summarised in Tables 3 and 4 . In situ cosmogenic ${ }^{10} \mathrm{Be}$ determinations listed in column 5 (with standard errors in column 6) were measured on quartz purified from fine sand fractions (see text).

$\mathrm{nr}^{*}$ indicates no result.

* indicates not analysed.

Radiocarbon ages for delta drill core samples were provided by Professor Li Congxian of the school of Ocean and Earth Science, Tongji University, Shanghai.

was taken to exclude silt particles, characteristic of wind-blown loess, because the greater part of China's loess comes from northern arid regions (Porter, 2001) and does not originate in the Yangtse River catchment. An aliquot of each sample was acid-digested and analysed for a selection of trace elements by ICPAES. A large aliquot of each sample (typically $\sim 200 \mathrm{~g}$ ) was cleansed of heavy minerals and reduced to $\sim 30 \mathrm{~g}$ of ultra-pure quartz, from which ${ }^{10} \mathrm{Be}$ was extracted using standard methods (Kohl and Nishiizumi, 1992). ${ }^{10} \mathrm{Be}$ was measured relative to a ${ }^{9} \mathrm{Be}$ spike by accelerator mass spectrometry (AMS) at the
Australian National University Heavy Ion Facility (Fifield, 1999).

\subsection{Sediment tracing}

Geochemical indices were used to assess the contributions from different sources to a given sample of Yangtse River sand. In principle, the proportion of sediment entering the Yangtse River from a given tributary can be estimated as

$$
F_{X}=\left(N_{X+Y}-N_{Y}\right) /\left(N_{X}-N_{Y}\right) ; \quad F_{Y}=1-F_{X}
$$


where $F_{X}$ is the proportion entering from tributary $X, F_{Y}$ is the proportion from the Yangtse River, $N_{X}$ is the measured concentration of a given tracer (e.g. $\% \mathrm{Mg}$ or ppm $\mathrm{Zn}$ ) in sand from tributary $X, N_{Y}$ is the concentration in Yangtse River sand upstream of the junction with tributary $X$, and $N_{X+Y}$ is the concentration in Yangtse River sand downstream of the junction.

\subsection{Erosion rates}

Catchment-averaged erosion rates were estimated from gauged sediment fluxes and from cosmogenic ${ }^{10} \mathrm{Be}$ in quartz particles. Gauge data give contemporary rates whereas ${ }^{10} \mathrm{Be}$ can be used to estimate rates averaged over the time taken for $\sim 2 \mathrm{~m}$ of surface lowering, which may be thousands to tens of thousands of years.

Gauge-based erosion rates were calculated as

$\varepsilon_{\mathrm{g}}=Q_{\mathrm{s}} / \rho A$

where $\varepsilon_{\mathrm{g}}$ is erosion rate expressed as lowering rate of a land surface $\left(\mathrm{m} \mathrm{Ma}^{-1}\right), \rho$ is the bulk density of rock (tonnes $\mathrm{m}^{-3}$ ), $Q_{\mathrm{s}}$ is annual sediment discharge (tonnes $\mathrm{yr}^{-1}$ ) and $A$ is the area of mountain and upland terrain in a given catchment, measured from topographic maps $\left(\mathrm{km}^{2}\right)$.

Erosion rates were also estimated from measurements of ${ }^{10} \mathrm{Be}$ in quartz, produced in situ by cosmic rays. The standard theory used for eroding surfaces assumes that erosion rate is constant (Lal, 1991; Gosse and Phillips, 2001), and we also assume that the average rate for a land surface can be estimated from ${ }^{10} \mathrm{Be}$ in sedimentary particles eroded from that surface. Both assumptions are examined further, below. From the theory developed by Lal (1991) for a surface eroding smoothly at a constant rate, the ${ }^{10} \mathrm{Be}$ content (atoms $\mathrm{g}^{-1}$ ) is a function of erosion rate $(\varepsilon)$,

$N_{10_{\mathrm{Be}}}=P_{\mathrm{o}} S /(\lambda+\mu \varepsilon)$

where $\mu=\rho / \Lambda, \mu$ is rock density, $\rho$ is mean free path of cosmic rays $\left(\sim 160 \mathrm{~g} \mathrm{~cm}^{-2}\right), \Lambda$ is the radioactive decay constant of ${ }^{10} \mathrm{Be}\left(4.56 \times 10^{-7} \mathrm{yr}^{-1}\right), P_{\mathrm{o}}$ is ${ }^{10} \mathrm{Be}$ production rate at the ground surface and $S$ is a shielding factor that varies with site slope and geometry (Dunne et al., 1999).

Erosion in the deep, steep valleys of the Yangtse River headwaters is dominated by large-scale landslides, which is not the smooth, uniform process assumed in Eq. (3). However, the average ${ }^{10} \mathrm{Be}$ content of landslide debris that originated from slope failure can readily be derived from the exposure-age equation:

$N_{{ }_{10}}(z, \tau)=P_{\mathrm{o}} S \exp (-\mu z)(1-\exp (-\lambda \tau)) / \lambda$ where $N_{\mathrm{Be}}(z, \tau)$ is the number of ${ }^{10} \mathrm{Be}$ atoms produced at depth $z$ beneath a surface that was exposed $\tau$ years previously (Lal, 1991). Assuming that a slope evolves by a series of slope-parallel landslides with recurrence interval $\tau$, the average ${ }^{10} \mathrm{Be}$ content in the debris of a given landslide at the time of slope failure is the depthaverage of (4):

${ }^{*} N_{{ }^{10}{ }_{\mathrm{Be}}}=P_{\mathrm{o}} S(1-\exp (-\lambda \tau)) / \mu h \lambda$

where $h$ is the depth of the failure surface, assumed to be more than a few metres below the ground surface. The long-term average erosion rate is $\bar{e}=h / \tau$, and if the interval between landslides on a given slope is relatively short so that $\lambda \tau \ll 1$ (e.g. $\tau<10^{5}$ years), then $* N_{\mathrm{Be}} \approx P_{\mathrm{o}} S /$ $\mu \bar{e}$. Similarly, when uniform erosion is relatively rapid so that $\mu \varepsilon \gg \lambda$, then (3) reduces to $N_{\mathrm{Be}} \approx P_{\mathrm{o}} S / \mu \varepsilon$. Hence, Eq. (3) can be used to evaluate average erosion rate from $* N_{\mathrm{Be}}$, if erosion is rapid and is dominated by landslides with a relatively short recurrence interval (e.g. $\bar{e}>100 \mathrm{~m} \mathrm{Ma}^{-1}$ and $\tau<10^{5}$ years).

The cosmogenic production rate $P_{\mathrm{o}}(z, \varphi)$ increases rapidly with altitude $(H)$ :

$P_{\mathrm{o}}(z)=a+b H+c H^{2}+d H^{3}$

(Lal, 1991). In terrain of high relief such as the Longmen Shan, $* N_{\mathrm{Be}}$ will vary substantially from slope base to crest although $\bar{e}$ may be the same at all points. To obtain an average value for a slope or catchment, ${ }^{*} N_{\mathrm{Be}}$ is summed over a series of altitude levels $H_{i}$, with $P_{\mathrm{o}}$ calculated by (6) at each level, to give

${ }^{*} N_{{ }_{10}{ }_{\mathrm{Be}}}[C]_{\bar{e}}=\sum a_{i}^{*} N_{{ }_{10} 0_{\mathrm{Be}}}\left(H_{i}\right)$

where $* N_{\mathrm{Be}}[C]_{\bar{e}}$ is the catchment average $* N_{\mathrm{Be}}$ for given a given erosion rate $\bar{e}, a_{i}$ is the fractional area at altitude level $i$, and $\Sigma a_{i}=1 . P_{\mathrm{o}}$ is calculated by (6) using latitude-dependent values for the coefficients $(a, b, c, d)$ given by Lal (1991), adjusted to more recent determinations of $P_{\mathrm{o}}$ at sea level (Stone, 2000).

\section{Results (1): Sediment tracing, sources and sinks}

Sediment gauging data indicate that net sediment flux decreases downstream of the Three Gorges (Fig. 2). This does not imply that sediment reaching the Yangtse River delta comes only from western sources, because additions from the eastern tributaries may be mixed into the load while the river passes through the lowlands, through trapping and reworking of contemporary sediments from both western and eastern inputs. Mixing may also involve reworking of Pleistocene sediment tracts. 
The origins of sediments reaching the delta may be determined mineralogically or geochemically, if sediments from different sources have different characteristics. A number of Chinese authors have explored the use of trace elements (Zhao and Yan, 1992; Zhang et al., 1998; Yang and Li, 1999) for sourcing sediments and have shown that geochemical signatures of Yangtse River and Yellow River sediments are significantly different. Whether there are significant differences between eastern and western Yangtse River sources is less clear, and to address this question the fine sand component (100-200 $\mu \mathrm{m}$ size) in each of our samples was analysed for selected elements. Cosmogenic ${ }^{10} \mathrm{Be}$ concentrations in quartz sand (data shown in Table 2) were also used as indicators of sand provenance. Our measurements from Yangtse River sand compare well with results reported by previous authors: Table 3 shows average values for selected elements in bulk sediment samples (Zhao and Yan, 1992; Huang and Zhang, 1994; Zhang et al., 1998; Yang and Li, 1999) together with our results from fine sand, from the Yangtse Delta and from sites in the eastern Yangtse River, downstream of the Three Gorges. The two data sets are very similar except that our measurements of $\mathrm{Al}$ are significantly lower than the previous results, which may reflect sample differences: bulk sediment analysed by previous authors is likely to include clay, relatively high in $\mathrm{Al}$, while we analysed the fine sand fraction.

The variation of geochemical tracers according to the relative proportions of sediment from different sources is illustrated in Fig. 4, which shows ${ }^{10} \mathrm{Be}$ data from tributaries to the Yangtse River in western Sichuan. For example, samples from the Min Jiang and Jinsha Jiang above its junction have ${ }^{10} \mathrm{Be}$ levels of $0.07 \times 10^{6}$ and $0.58 \times 10^{6}$ atoms $g^{-1}$, respectively, while a sample from the Yangtse River further downstream (below the relatively small Tuo Jiang) has $0.44 \times 10^{6}$ atoms $\mathrm{g}^{-1}$. Assuming that the Tuo Jiang and Min Jiang have similar ${ }^{10} \mathrm{Be}$ values (they share similar sources), the Min-Tuo system contributes $27 \%$ of the combined sediment load in the Yangtse River below their confluence (calculated using Eq. (1)). This compares reasonably well with sediment gauging data (Table 1), which indicate that the Min-Tuo system contributes $20 \%$ of the load. A similar mixing pattern is seen in Fig. 4 at the junction of the Yalong Jiang and Jinsha Jiang: the figures suggest that the Yalong Jiang contributes $\sim 65 \%$ of the combined load, but here we have no gauging data as a crosscheck.

Progressive mixing of sediments from different sources is also apparent when the geochemical signatures of sediments from major tributaries are followed downstream. Table 4 presents average levels of $\mathrm{Mg}, \mathrm{Ca}$,

Table 3

Selected elements in sediments from the Yangtse Delta and the eastern Yangtse River

\begin{tabular}{|c|c|c|c|c|c|c|c|c|c|c|}
\hline & \multicolumn{4}{|c|}{ Previous data } & \multicolumn{6}{|c|}{ This study } \\
\hline & \multicolumn{2}{|l|}{ Modern } & \multicolumn{2}{|c|}{ Eastern } & \multicolumn{2}{|c|}{ Modern } & \multicolumn{2}{|c|}{ Holocene } & \multicolumn{2}{|l|}{ Eastern } \\
\hline & \multicolumn{2}{|l|}{ Delta $^{a}$} & \multicolumn{2}{|c|}{ Yangtse $^{\mathrm{b}}$} & \multicolumn{2}{|l|}{ Delta $^{c}$} & \multicolumn{2}{|l|}{ Delta $^{\mathrm{d}}$} & \multicolumn{2}{|c|}{ Yangtse $^{\mathrm{e}}$} \\
\hline & Mean & \pm S.E. ${ }^{\mathrm{f}}$ & Mean & \pm S.E. & Mean & \pm S.E. & Mean & \pm S.E. & Mean & \pm S.E. \\
\hline \multicolumn{11}{|c|}{ Major elements, \% } \\
\hline $\mathrm{Mg}$ & 1.6 & 0.2 & $\mathrm{nd}^{\mathrm{g}}$ & $\mathrm{nd}^{\mathrm{g}}$ & 1.3 & 0.15 & 1.1 & 0.13 & 1.7 & 0.3 \\
\hline $\mathrm{Ca}$ & 2.9 & 0.3 & 3.3 & 0.3 & 3.0 & 0.2 & 3.3 & 0.7 & 4.0 & 1.0 \\
\hline $\mathrm{Al}$ & 6.5 & 0.3 & 7.1 & 0.3 & 5.1 & 0.8 & 5.0 & 0.4 & 4.7 & 0.2 \\
\hline $\mathrm{Ti}$ & 0.56 & 0.05 & 0.6 & 0.03 & 0.24 & 0.02 & 0.19 & 0.05 & 0.25 & 0.04 \\
\hline $\mathrm{Fe}$ & 3.8 & 0.2 & 4.2 & 0.2 & 3.0 & 0.7 & 2.5 & 0.3 & 3.5 & 0.6 \\
\hline \multicolumn{11}{|c|}{ Minor elements, ppm } \\
\hline $\mathrm{Sr}$ & 140 & 6 & 130 & 6 & 163 & 5 & 190 & 22 & 245 & 35 \\
\hline $\mathrm{Ba}$ & 440 & 30 & 435 & 15 & 395 & 32 & 400 & 16 & 430 & 35 \\
\hline $\mathrm{Mn}$ & 870 & 40 & 870 & 40 & 670 & 210 & 570 & 90 & 610 & 85 \\
\hline $\mathrm{Zn}$ & 110 & 12 & 130 & 10 & 95 & 16 & 97 & 30 & 150 & 50 \\
\hline
\end{tabular}

Columns 1-4: previous results from bulk sediment.

Columns 5-10: results for fine sand fraction, this work.

a Zhao and Yan (1992), Huang and Zhang (1994), Yang and Li (1999), Zhang et al. (1998).

b Zhang et al. (1998).

c Samples from area 1a (location, Fig. 1).

${ }^{\mathrm{d}}$ Drillhole samples from sites $1 \mathrm{~b}$ and 1c (locations, Fig. 1; radiocarbon ages, Table 2).

e Samples from sites 2, 5, 8, 9 (locations, Fig. 1).

f S.E. = standard error.

g No Mg data in Zhang et al. (1998). 


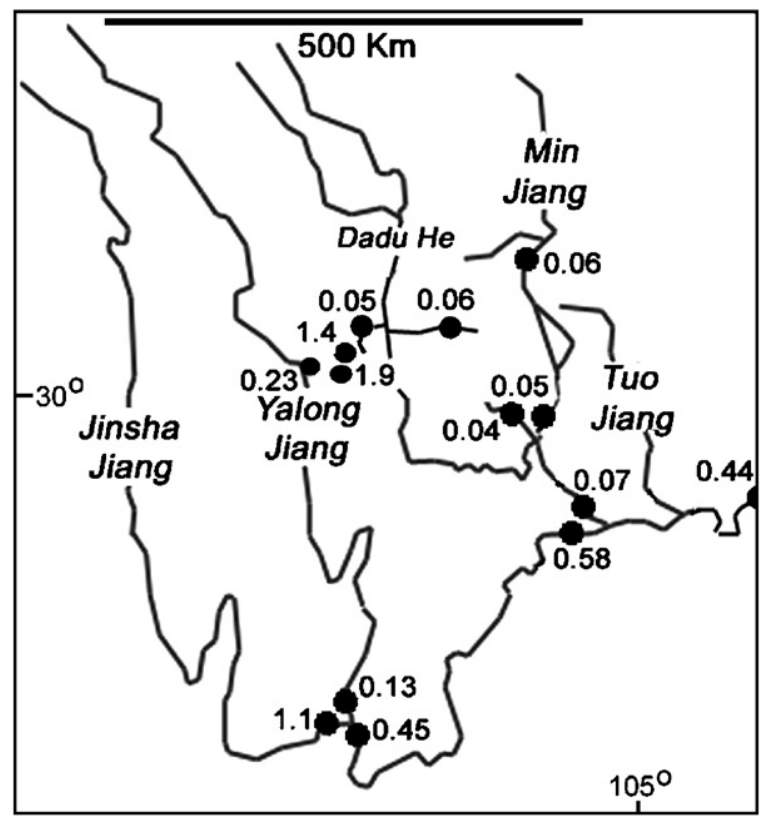

Fig. $4 .{ }^{10} \mathrm{Be}_{\mathrm{s}}$ signatures (atoms $\mathrm{g}^{-1} \times 10^{6}$ ) in quartz sand extracted from sites in major western Yangtse River tributaries.

$\mathrm{Sr}, \mathrm{Ti}, \mathrm{Mn}$ and $\mathrm{Fe}$ in sand samples from the major western rivers (the Jinsha and Min river systems: sites 11-19) and from the Jialing Jiang which drains the Sichuan Basin (2 samples from site 10), together with averages for the four major eastern tributaries (the Yuan, Xiang, Han and Gan rivers: sites 3-7). Table 4 also gives averages for the combined modern and Holocene delta samples. Average concentrations of all elements are highest in samples from the Jinsha and Min rivers; are lower in samples from the Jialing Jiang, and are lowest in the samples from the major eastern tributaries. Also shown is the estimated composition of sediment leaving the Sichuan Basin (Table 4, row 4), obtained by adding the compositions of the contributory river systems in the proportions of their gauged sediment fluxes, which are given in Table 1. Statistically, these estimates are comparable with the results for our sample from the Yangtse River at Yichang (site 9), which is about $500 \mathrm{~km}$ further downstream and receives the combined sediment from Sichuan and other tributaries, notably the $\mathrm{Wu}$ Jiang (location: Fig. 1). In summary, the concentrations of $\mathrm{Mg}, \mathrm{Ca}, \mathrm{Sr}, \mathrm{Ti}, \mathrm{Mn}$ and $\mathrm{Fe}$ in river sand from the western rivers are modestly diluted by the Jialing Jiang but remain relatively high, downstream to Yichang. Average values for sand from the eastern tributaries are substantially lower.

The composition of the delta sediments is intermediate between the eastern and western sources, suggesting that the delta contains a significant proportion of sand from the eastern tributaries. Assuming that the Yichang data represent the combined western sources, the contribution from eastern sources was calculated for each element by Eq. (1) and ranges from $17 \%$ to $54 \%$ of the total (Table 4, columns 1-6). Similar results flow from cosmogenic ${ }^{10} \mathrm{Be}$ in fine sand-size quartz, separated from our bulk sediment samples (Table 4, column 7). Collectively, the elemental and ${ }^{10} \mathrm{Be}$ data in Table 4 indicate that $35 \pm 5 \%$ of the delta sand comes from sources in the eastern Yangtse River catchment. Moreover, there is no evidence for any significant change in the last 10,000 years, as the compositions of our modern and Holocene delta samples are statistically the same (Table 3 ). An eastern contribution of $\sim 35 \%$ is

Table 4

Selected elements and in situ cosmogenic ${ }^{10} \mathrm{Be}_{\mathrm{s}}$ in fine sand from western sources, eastern sources and Yangtse River delta (primary ${ }^{10} \mathrm{Be}_{\mathrm{s}}$ data are listed in Table 2)

\begin{tabular}{|c|c|c|c|c|c|c|c|}
\hline & $\operatorname{Mg}(\%)$ & $\mathrm{Ca}(\%)$ & $\operatorname{Sr}(\%)$ & $\mathrm{Ti}(\%)$ & Mn (\%) & $\mathrm{Fe}(\%)$ & ${ }^{10} \mathrm{Be}\left(\right.$ atoms $\left.\mathrm{g}^{-1} \times 10^{6}\right)$ \\
\hline \multicolumn{8}{|l|}{ Western rivers } \\
\hline Jinsha & 1.8 & 4.8 & 0.022 & 0.51 & 0.077 & 4.6 & 0.58 \\
\hline Min & 1.5 & 4.4 & 0.021 & 0.31 & 0.074 & 3.6 & 0.07 \\
\hline Jialing & 0.6 & 2.7 & 0.018 & 0.11 & 0.032 & 1.9 & 0.16 \\
\hline Jinsha, Min, Tuo and Jialing ${ }^{\mathrm{a}}$ & 1.5 & 4.3 & 0.020 & 0.40 & 0.068 & 3.9 & 0.41 \\
\hline Yangtse at Yichang & 1.6 & 4.9 & 0.025 & 0.34 & 0.067 & 4.0 & $0.41^{\mathrm{b}}$ \\
\hline Eastern rivers ${ }^{\mathrm{c}}$ & 0.35 & 0.49 & 0.001 & 0.014 & 0.039 & 1.6 & 0.12 \\
\hline Delta, means ${ }^{\mathrm{d}}$ & 1.2 & 3.2 & 0.018 & 0.21 & 0.062 & 2.7 & 0.30 \\
\hline$\%$ From eastern rivers ${ }^{\mathrm{e}}$ & 32 & 38 & 29 & 39 & 17 & 54 & 38 \\
\hline
\end{tabular}

${ }^{a}$ Estimated composition of Yangtse River sand leaving Sichuan, based on the sum of Jinsha, Min, Tuo and Jialing data, weighted according to gauged sediment fluxes given in Table 1. The composition of Tuo River sand is assumed to be the same as that of the Min Jiang, as it has a very similar source.

${ }^{\mathrm{b}}$ Sample yielded no result; figure taken from upstream sum.

c Averages of samples from the Yuan, Xiang, Han and Gan rivers.

d Averages of modern and Holocene delta samples, combined.

e Calculated with Eq. (1) assuming that Yichang data represent the sum of western sources. 
unexpectedly high, considering the size and extent of mountain tracts in the west. To sustain this figure, the sediment yield (tonnes $\mathrm{km}^{-2} \mathrm{yr}^{-1}$ ) from uplands in the eastern catchments would need to approach that of the west, which seems unlikely and is difficult to reconcile with estimates of long-term erosion rates in eastern and western catchments, described below.

\section{Results (2): Recent and long-term erosion rates}

Regional erosion rates may be estimated from both sediment gauge data, and cosmogenic ${ }^{10} \mathrm{Be}$ in quartz. In principle, gauge data give contemporary rates whereas ${ }^{10} \mathrm{Be}$ can be used to estimate rates averaged over the time taken for $\sim 2 \mathrm{~m}$ of surface lowering, which may be thousands to tens of thousands of years. In the context of our regional-scale study, both methods are weakened by assuming that processes operating across a region can meaningfully be described by an "average" rate, which is unrealistic in the large catchments sampled here. Moreover, the two methods see the eroding landscape differently: catchment-scale rates based on sediment gauging are averaged over the catchment area and will tend to be lower than estimates from terrestrial cosmogenic nuclides in the same catchment, which respond to erosion rates at the points of sediment production.

\section{1. (i) Gauge-based estimates}

Erosion is the subject of on-going study in China, and gauge-based estimates of catchment sediment yields in tonnes $\mathrm{km}^{-2} \mathrm{yr}^{-1}$ throughout the Yangtse basin are summarised in maps published by the Yangtse Water Control Committee (YWCC, 2001). Table 5, column 1, lists erosion rates for selected tributary catchments derived from these maps. Independently, we reduced the sediment fluxes given in Table 1 to catchment-average erosion rates, using catchment areas measured from topographic maps (numbers in brackets, Table 5). The two sets of estimates are consistent, other than our estimate for the Jialing Jiang (165 $\left.\mathrm{mm} \mathrm{kyr}^{-1}\right)$, which lies below the range given by YWCC (2001) (180$350 \mathrm{~mm} \mathrm{kyr}^{-1}$ ). The method assumes that recorded fluxes are not unduly affected by in-channel factors such as weirs, dams and severely eroding banks, and the results give no indication of erosion maxima or minima within a catchment.

As might be expected, Table 5 indicates that catchment erosion in the Longmen Shan is more rapid than in the eastern tributaries of the Yangtse River. It is perhaps surprising that the Longmen Shan rates are not
Table 5

Catchment-averaged erosion rates from sediment yields based on gauged sediment fluxes and on ${ }^{10} \mathrm{Be}_{\mathrm{s}}$ in quartz grains from fine sand

\begin{tabular}{lll}
\hline & Sediment yield ${ }^{\mathrm{a}}$ & ${ }^{10} \mathrm{Be}$ \\
\hline Eastern catchments & $35-70(60)$ & $30-50$
\end{tabular}

Central catchments

Jialing Jiang 180-350 (140)

Western mountains

$\begin{array}{lll}\text { Min Jiang } & 180-350(185) & 300-500 \\ \text { Xiao Jin Chuan } & 180-350 & 400-600 \\ \text { Upper Danba } & 180-350 & 700-900\end{array}$

Mountain $(M)$ - Plateau $(P)$ catchments

Jinsha-Yalong Jiang $\quad$ 100-300 (250) 400-600 (M) $15-25(\mathrm{P})$

Plateau

Upper Yalong Jiang $\quad 18-35 \quad 20-30(\mathrm{~S})^{\mathrm{b}}$ $20-25(\mathrm{O})^{\mathrm{b}}$

${ }^{a}$ Estimates based on gauged sediment loads and catchment areas, from YWCC (2001); figures in parentheses are based on sediment fluxes in Table 1, and catchments areas measured from maps by the authors.

${ }^{\mathrm{b}}$ Plateau rates based on ${ }^{10} \mathrm{Be}$ in quartz sand and pebbles from local streams (S), and from bedrock surfaces outcropping through thin soil (O).

higher, considering that the mountains are steep, high and tectonically active, and that the catchment rate for the Jialing Jiang, draining the Sichuan Basin, appears to be only slightly different from that of the Longmen Shan. These results are considered further, below.

\subsection{1. ${ }^{10}$ Be-based estimates}

In principle, erosion rates can be estimated from ${ }^{10} \mathrm{Be}$ in sedimentary particles $\left({ }^{10} \mathrm{Be}_{\mathrm{s}}\right)$ derived from uniformly eroding hillslopes, provided that the time taken for the sediment to travel from erosional sources to the sediment sampling point is so rapid that the cosmogenic nuclide content does not change appreciably, either by further production or by radioactive decay. In studies of small catchments dominated by soil creep, Heimsath et al. (2000) showed that erosion rates based on ${ }^{10} \mathrm{Be}$ and ${ }^{26} \mathrm{Al}$ in stream sediments were close to the averages for representative sets of hillslope samples. Our results, below, indicate that in suitable circumstances, reasonable estimates of average erosion rates can be obtained from ${ }^{10} \mathrm{Be}_{\mathrm{s}}$ measurements from sediment in large catchments.

Relationships between $* N_{\mathrm{Be}}[\mathrm{C}]$ and average erosion rate $\bar{e}$ were calculated for three contrasting catchment types in the Yangtse River system: eastern catchments comprised of lowlands, dissected hills and lesser 
mountains ranging to $1600-2000 \mathrm{~m}$; mountain catchments with deep, steep-walled valleys $1000-2500 \mathrm{~m}$ deep within mountain ranges rising to over $5500 \mathrm{~m}$, and composite plateau and mountain catchments comprised of high-altitude plateau as well as mountains and deep valleys. The three types are represented by the Xiang and Yuan rivers, the Min-Dadu river system, and the upper Jinsha Jiang, respectively. To evaluate ${ }^{10} \mathrm{Be}$ production across each catchment, we established hypsometric (height-area) models for representative areas of each catchment type, based on digital elevation data and topographic maps (Fig. 5a). Curves of $* N_{\mathrm{Be}}[\mathrm{C}]$ vs. $\bar{e}$ were calculated for each model, using Eqs. (3), (6) and (7) (Fig. 5b). Altitude steps used were $100 \mathrm{~m}$ for the eastern catchment model and $200 \mathrm{~m}$ for the mountain and composite mountain/plateau catchment models.

Making the assumption that ${ }^{10} \mathrm{Be}_{\mathrm{s}} \approx * N_{\mathrm{Be}}[C]$, average erosion rates were estimated for each catchment type by plotting measured ${ }^{10} \mathrm{Be}_{\mathrm{s}}$ onto the appropriate curve of ${ }^{*} N_{\mathrm{Be}}[C]$ vs. $\bar{e}$. Using the eastern hypsometric model, this procedure gives a mean erosion rate of $30-50 \mathrm{~m} \mathrm{Ma}^{-1}$ for the Xiang, Yuan and Gan river catchments, which have measured ${ }^{10} \mathrm{Be}_{\mathrm{s}}=0.14 \pm 0.02 \times 10^{6}$ atoms $\mathrm{g}^{-1}$ (shown as box XYG in Fig. 5b). The mountain hypsometric model represents the high mountainous Min-Dadu catchment, for which the measured values of ${ }^{10} \mathrm{Be}_{\mathrm{s}}$ from the Min Jiang $\left(0.055 \pm 0.013 \times 10^{6}\right.$ atoms $\left.^{-1}\right)$ give a mean rate of $300-500 \mathrm{~m} \mathrm{Ma}^{-1}$ (shown as box Min
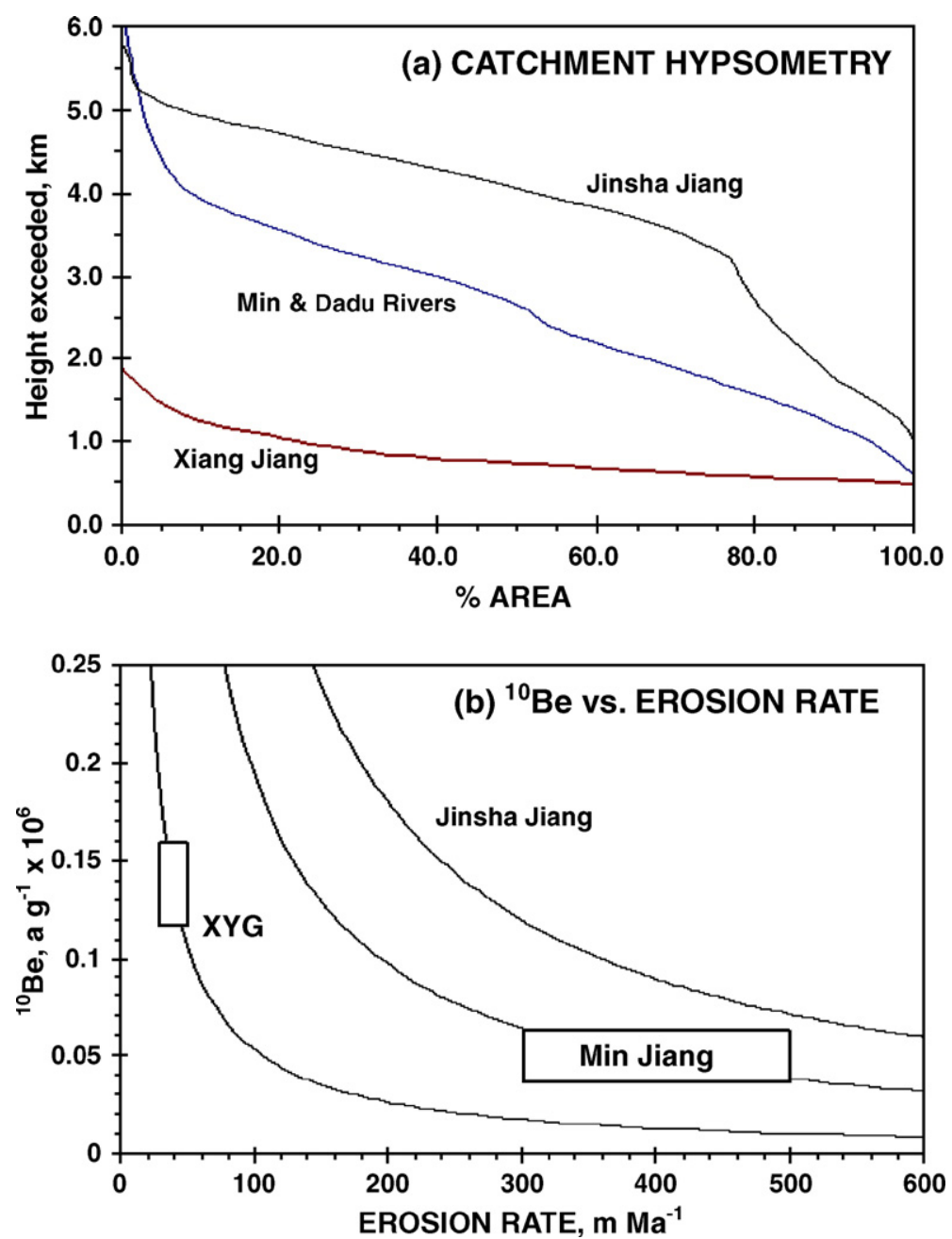

Fig. 5. (a) Hypsometric (cumulative area - altitude) curves for representative Yangtse River catchments, used for erosion-rate modelling. The Xiang Jiang curve omits low-gradient lowlands. (b) ${ }^{10} \mathrm{Be}_{\mathrm{s}}$ versus erosion rate for the Xiang Jiang, Min-Dadu system and Jinsha Jiang catchments, calculated for the hypsometric curves shown in (a), assuming that erosion is uniform and that the time taken for grains to travel from eroding sources to river bed is negligible. Mean values of ${ }^{10} \mathrm{Be}_{\mathrm{s}}$ for samples from the Xiang, Yuan and Gan rivers (XYG) and the Min Jiang are superimposed on curves of ${ }^{10} \mathrm{Be}$ vs. erosion rate for their respective hypsometries; box sizes represent standard errors. 
Jiang in Fig. 5b). Average erosion rates were also estimated from samples collected in two smaller rivers within the Longmen Shan, the Xiao Jin Chuan (site 20), which is hypsometrically similar to the Min Jiang above $2000 \mathrm{~m}$, and the upper Danba river (site 21), which resembles the Min Jiang catchment above $3300 \mathrm{~m}$. Estimated rates were 400-600 and 700-900 $\mathrm{m} \mathrm{Ma}^{-1}$ for the Xiao Jin Chuan stream and the upper Danba River, respectively (Table 5).

In deriving these estimates, it is assumed that erosion is uniform throughout each catchment, and that sediment travelled rapidly from eroding sources to the sampling sites. Departures from either assumption will introduce errors. Exposure to cosmic rays during sediment transport will cause erosion rate estimates from ${ }^{10} \mathrm{Be}_{\mathrm{s}}$ to be too low, but this error should be relatively small in the deep mountain valleys of the Longmen Shan because cosmogenic production rates of ${ }^{10} \mathrm{Be}$ will be significantly less than on the eroding mountainsides, owing to combined effects of low altitude and shielding. However, ${ }^{10} \mathrm{Be}_{\mathrm{s}}$ erosion rates based on uniform catchment erosion can be seriously too low, when a sample includes sediment from slowly eroding areas at high altitude. Our samples from the Jinsha Jiang are a case in point: two samples from the Jinsha Jiang at Panzhihua (site 19) gave ${ }^{10} \mathrm{Be}_{\mathrm{s}}=1.1 \pm$ $0.1 \mathrm{~m} \mathrm{Ma}^{-1}$, over ten times higher than values from the Min-Dadu river samples despite that their deep, steep, landslide-dominated valleys are similar.

The Jinsha Jiang catchment differs from that of the Min Jiang and Dadu He in that it includes substantial tracts of plateau, which are likely to be eroding at a lower rate than the steep, landslide-dominated mountain valleys. Mountain and plateau rates cannot both be evaluated from downstream measurements of ${ }^{10} \mathrm{Be}_{\mathrm{s}}$, unless one rate or the other is known beforehand. Guessing that the average slope erosion in the deep valleys of the Jinsha Jiang is similar to that in the MinDadu river catchment, $* N_{\mathrm{Be}}[C]$ was calculated for a range of plateau erosion rates, with the rate for mountains and landslide-dominated valleys set at 300 $500 \mathrm{~m} \mathrm{Ma}^{-1}$. The Jinsha Jiang hypsometry shown in Fig. 5a was partitioned, with plateau assumed to comprise $90 \%$ of the terrain between 3800 and $4700 \mathrm{~m}$ altitude (about $40 \%$ of the catchment area) and the remainder was treated as mountains and deep valleys. Fig. 6a shows results; plotting ${ }^{10} \mathrm{Be}_{\mathrm{s}}$ measured from Jinsha samples $\left(1.1 \pm 0.1 \times 10^{6}\right.$ atoms $\left.\mathrm{g}^{-1}\right)$ on this diagram gives a plateau erosion rate of $15-25 \mathrm{~m} \mathrm{Ma}^{-1}$ (Table 5). Although this result rests on several broad assumptions, it is consistent with ${ }^{10} \mathrm{Be}$ erosion rates from the plateau itself, which were determined from four collections of quartz chips from in situ rock surfaces as well as sediment in small streams $\left(20-30 \mathrm{~m} \mathrm{Ma}^{-1}\right.$ in areas 22 and 23: Fig. 1; ${ }^{10} \mathrm{Be}$ data in Table 2). These results are listed in Table 5 as "Plateau, upper Yalong Jiang".

Finally, the observed sediment yield of the Jinsha Jiang is consistent with plateau erosion at $20-30 \mathrm{~m} \mathrm{Ma}^{-1}$ and erosion of $\sim 400 \mathrm{~m} \mathrm{Ma}^{-1}$ in the mountain terrain, as the following simple calculation shows. The total

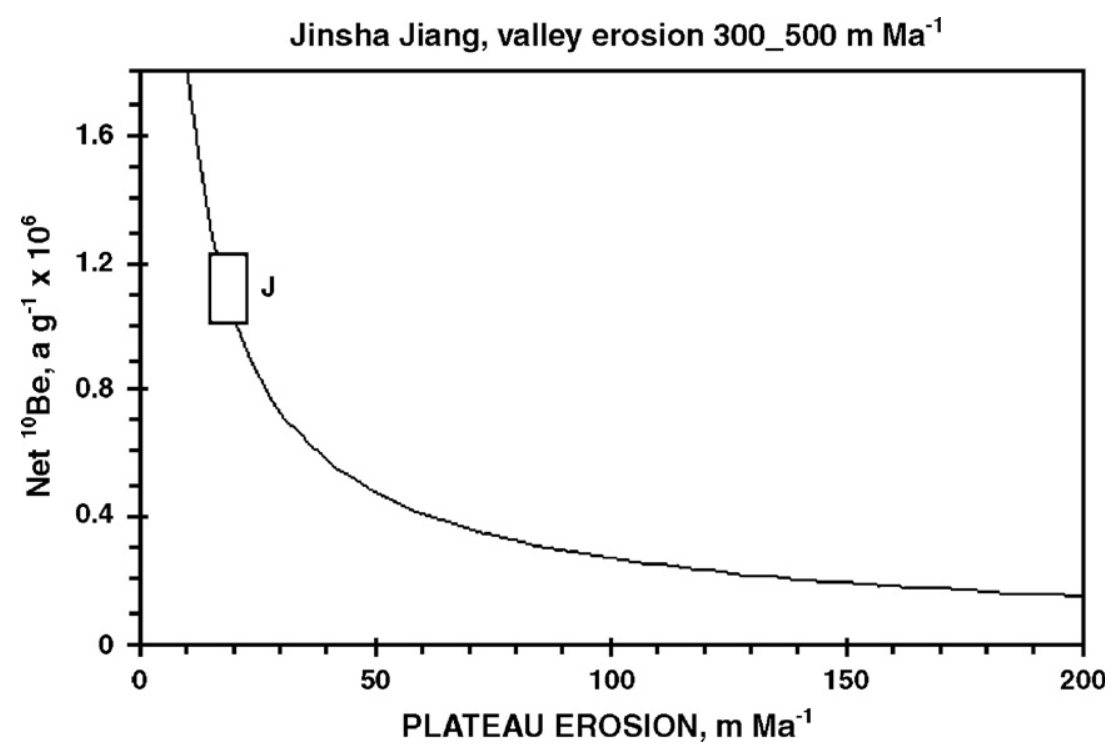

Fig. $6 .{ }^{10} \mathrm{Be}_{\mathrm{s}}$ vs. plateau erosion rate for catchment with Jinsha hypsometry where valley and mountains slopes erode at $300-500 \mathrm{~m} \mathrm{Ma}{ }^{-1}$ and plateau comprises $90 \%$ of the terrain between 3800 and $4700 \mathrm{~m}$ altitude. Box at $\mathrm{J}$ represents ${ }^{10} \mathrm{Be}_{\mathrm{s}}$ for samples from Jinsha at Panzhihua (location, Fig. 1). 
sediment yield from plateau and mountains is $S=\rho\left(\bar{e}_{\mathrm{p}} A_{\mathrm{p}}\right.$ $\left.+\bar{e}_{\mathrm{m}} A_{\mathrm{m}}\right)$, where $\bar{e}_{\mathrm{p}}, \mathrm{A}_{\mathrm{p}}$ and $\bar{e}_{\mathrm{m}}, A_{\mathrm{m}}$ are average erosion rates and areas, respectively, for the plateau (p) and mountain (m) parts of the Jinsha Jiang catchment, and $\rho$ is rock density. With $A_{\mathrm{p}}=1.5 \times 10^{5} \mathrm{~km}^{2}, A_{\mathrm{m}}=2.1 \times$ $10^{5} \mathrm{~km}^{2}$ and $\bar{e}_{\mathrm{p}}=25 \mathrm{~m} \mathrm{Ma}^{-1}, \bar{e}_{\mathrm{m}}=400 \mathrm{~m} \mathrm{Ma}^{-1}$, the expected yield is $\sim 240 \times 10^{6} \mathrm{t} \mathrm{yr}^{-1}$, which equals the observed annual sediment flux given in Table 1 for the Jinsha Jiang at Pinshan (Pinshan is location P, Fig. 1).

To summarise, Table 5 shows estimated regional erosion rates for selected western and eastern catchments, based both on both gauging and ${ }^{10} \mathrm{Be}_{\mathrm{s}}$. No estimates were made for the Jialing Jiang and Han Shui catchments, which extend north into landscapes mantled by deep loess. In situ production of ${ }^{10} \mathrm{Be}$ is suppressed by the loess cover and calculated erosion rates are likely to be unrealistic, unless well constrained with data from outcrops and small catchments. Further confirmation of the estimates for western sources from mountain and plateau samples is in progress, based on samples collected in July 2004, while eastern hillslope and mountain sources have yet to be sampled.

\section{Conclusions}

The results derived above confirm some expectations but also carry some surprises. That the estimated catchment erosion rate for major eastern tributaries of the Yangtse River are substantially lower than for the western mountain catchments is to be expected, but it seems surprising that the rates for the western mountain catchments are not higher, given that erosion rates in steep, landslide-dominated mountainous terrain elsewhere are much greater. In the New Zealand Alps, for example, where landslides also dominate erosion, rates of 2000-18,000 $\mathrm{m} \mathrm{Myr}^{-1}$ have been determined from catchment sediment yields (Griffiths, 1981; Hovius et al., 1997). At 180-350 $\mathrm{m} \mathrm{Myr}^{-1}$, gauge-based erosion rates for the mountainous Jinsha-Yalong and MinDadu river systems are more than an order of magnitude smaller than these results from the New Zealand Alps.

Gauge-based erosion rates for the western mountains doubtless are lowered by inclusion of areas of low erosion. For example, the gauge-based average rate in the Jinsha Jiang catchment is $250 \mathrm{~m} \mathrm{Ma}^{-1}$; excluding the plateau, the rate is $400 \mathrm{~m} \mathrm{Ma}^{-1}$. Gauge-based estimates from small catchments in the Longmen Shan almost certainly would be higher than the figures from large catchments, presented here. Rates determined from

${ }^{10} \mathrm{Be}_{\mathrm{s}}$ tend to reflect rates at actively eroding sites and, provided that erosion is uniform across the region of interest, rates based on ${ }^{10} \mathrm{Be}_{\mathrm{s}}$ are liable to be higher than gauge-based estimates in eroding terrain (Table 5). Results in Table 5 show this tendency. However, estimates based on ${ }^{10} \mathrm{Be}$ will be less than the true rate if some of the sediment comes from slowly eroding areas at high altitude, or if the sediment had prolonged exposure to cosmic rays during transport. Errors arising from slow transport sediment are likely to be small in samples from deep valleys within the Longmen Shan, as explained above, but may be more significant in the eastern catchments, where the passage of sediment through the broad valleys is likely to include episodes of stasis in floodplain deposits. Where the catchment includes a substantial area of high plateau, as in the Jinsha Jiang, the plateau and mountain erosion rates must be evaluated separately.

In summary, the catchment erosion rates listed in Table 5 probably underestimate averages for the most actively eroding areas within the Yangtse River basin, such as in landslide-dominated major valleys of the Longmen Shan, but consistency between estimates from sediment gauging and from ${ }^{10} \mathrm{Be}_{\mathrm{s}}$ suggests that the rates are broadly realistic. Although samples are few, good agreement between local erosion rates based on ${ }^{10} \mathrm{Be}$ from outcrops and small streams on the plateau, and catchment-scale estimates based on ${ }^{10} \mathrm{Be}_{\mathrm{s}}$ and hypsometric modeling, lends further support. Overall, the results encourage further use of ${ }^{10} \mathrm{Be}_{\mathrm{s}}$ measurements as a means of assessing catchment-scale erosion rates, preferably with closer sampling than used here. Finally, it is noteworthy that historical rates based on gauging and longer-term rates from ${ }^{10} \mathrm{Be}_{\mathrm{s}}$ are similar, and the figures do not provide clear evidence for historical acceleration of erosion, at least at the catchment scale. This apparently null result almost certainly is attributable to scale: humanly-induced erosion is very evident in parts of the Yangtse River catchment but smallerscale studies than ours are needed, to assess the degree of acceleration.

As well as being the means of estimating erosion rates, ${ }^{10} \mathrm{Be}_{\mathrm{s}}$ proved to be a useful indicator of sediment provenance. A reconnaissance based on the concentrations of selected elements $(\mathrm{Mg}, \mathrm{Ca}, \mathrm{Sr}, \mathrm{Ti}, \mathrm{Mn} \mathrm{Fe})$ together with ${ }^{10} \mathrm{Be}_{\mathrm{s}}$ in sand samples from most of the major rivers in the Yangtse River basin suggests that about $35 \%$ of the sediment in the Yangtse River delta came from major tributaries that join the Yangtse River in the eastern lowlands - the Yuan, Xiang, Han and Gan rivers. Drill core samples from the delta suggest that this figure has not changed much in the last 10,000 years. This was a surprise. We expected that proportion of sediment reaching the delta from the eastern catchments would be less than allowed by long-term sediment 
yields from the eastern catchments, because the eastern lowlands comprise a vast, complex sediment trap. The sediment flux in the Yangtse River decreases downstream of the Three Gorges despite that the water discharge increases (Fig. 2) and much sediment from the eastern sources is trapped in lakes before reaching the Yangtse River.

If no sediment were trapped en route to the delta, the contribution from the eastern catchments would be governed by erosion rates and contributing area. The figures in Table 5 show that rates based on both sediment gauging and ${ }^{10} \mathrm{Be}_{\mathrm{s}}$ from the Yuan Jiang and Xiang Jiang catchments are about ten times lower than from the western mountains (Table 5); the Gan Jiang is expected to be similar. Considering that mountains generally are dominant sources of sediment, rather than pre-agricultural forested lowlands, and that the mountain areas in the west are larger than that in the east, it seems likely that slightly more than $10 \%$ of the sediment in the eastern Yangtse River basin could come from the Yuan, Xiang and Gan rivers. Sediment from the Han Shui must also be included: the gauged load of $57 \times 10^{6} \mathrm{t} \mathrm{yr}^{-1}$ (Table 1) could raise the total eastern contribution to $\sim 20 \%$ but this is an upper figure, as the Han Shui load has almost certainly increased with agricultural intensification in the loessic headwaters.

If we accept that $\sim 35 \%$ of the sediment in the Yangtse Delta came from the eastern catchments, as geochemical fingerprints suggest, two questions are raised: (i) have the eastern and/or the western sediment inputs changed, and (ii) how has sediment from the two source regions been mixed? Answers to both may lie with Pleistocene changes of climate and sea level. The balance of sediment inputs from east and west may have changed: under drier and colder glacial-age conditions, sediment transport from the western catchments may have been less than today, while erosion in the east, under reduced forest cover, could been greater. Glacialage sediments deposited in the eastern lowlands could be reworked and mixed with sediments entering from the west during post-glacial sea level rise; continual reworking and trapping would have been sister processes operating in different parts of the lacustrine and floodplain system. The mixing processes in the eastern lowlands may have been associated with shifting patterns of river channels, lakes and wetlands as floodplains aggraded throughout the post-glacial sea level rise; historical sedimentary infilling of lakes such as Dongting Lake may reflect as yet incomplete equilibration to the present sea level high-stand.

Considering the great size of the Yangtse River system and the sparse nature of our sampling, our estimates of sediment trapping, mixing and regional erosion are highly preliminary and inevitably will be modified in future by more detailed work. However, this reconnaissance study represents a bridge between environmental history at the human scale and at the geological scale, and shows how cosmogenic nuclides can enhance the geochemical toolkit. The data illustrate how patterns of sediment production and mixing during the passage from source to sink, although complex, can be separated one from the other with this enhanced toolkit.

\section{Acknowledgments}

We gratefully acknowledge support from the National Science Foundation of China, and especially thank Professors Wang Pinxian and Li Congxian of the Laboratory for Marine Geology at Tongji University, for support and also for drill core samples.

\section{References}

Derbyshire, E., Shi, Y.F., Li, J.J., Zheng, B.Y., Li, S.J., Wang, J.T., 1991. Quaternary glaciation of Tibet: the geological evidence. Quaternary Science Reviews 10, 485-510.

Dunne, J., Elmore, D., Muzikar, P., 1999. Scaling factors for the rates of production of cosmogenic nuclides for geometric shielding and attenuation at depth on sloped surfaces. Geomorphology 27, $3-11$.

Elvin, M., 2004. The Retreat of the Elephants. Yale University Press, New Haven.

Elvin, M., Su, Ninghu, 1998. The influence of the Yellow River on Hangzhou Bay since A.D. 1000. In: Elvin, Mark, Liu, Ts'ui-jung (Eds.), Sediments of Time: Environment and Society in Chinese History. Cambridge University Press, pp. 344-407.

Fifield, L.K., 1999. Accelerator mass spectrometry and its applications. Reports on Progress in Physics 62, 1223-1274.

Gosse, J.C., Phillips, F.M., 2001. Terrestrial in situ cosmogenic nuclides: theory and application. Quaternary Science Reviews 20, 1475-1560.

Griffiths, G.A., 1981. Some suspended sediment yields from South Island catchments, New Zealand. Water Resources Bulletin 17, 662-671.

Heimsath, A.M., Chappell, J., Dietrich, W.E., Nishiizumi, K., Finkel, R.C., 2000. Soil production on a retreating escarpment in southeastern Australia. Geology 28, 787-790.

Hori, K., Saito, Y., Zhao, Q., Cheng, X., Wang, P., Sato, Y., Li, C., 2001. Sedimentary facies and Holocene progradation rates of the Changjiang Yangtze delta, China. Geomorphology 41, 2001.

Hovius, N., Stark, C.P., Allen, P.A., 1997. Sediment flux from a mountain belt derived from landslide mapping. Geology 25, 231-234.

Huang, W., Zhang, J., 1994. Transport of chemical elements from Chang Jiang to East Sea. Acta Oceanologica Sinica 16 (2), 54-61 (in Chinese).

Kohl, C.P., Nishiizumi, K., 1992. Chemical isolation of quartz for measurement of in-situ-produced cosmogenic nuclides. Geochimica Cosmochimica Acta 56, 3583-3587. 
Lal, D., 1991. Cosmic ray labeling of erosion surfaces: in situ nuclide production rates and erosion models. Earth and Planetary Science Letters 104, 424-439.

Li, C., Chen, Q., Zhang, J., Yang, S., Fan, D., 2000. Stratigraphy and palaeoenvironmental changes in the Yangtse Delta during the Late Quaternary. Journal of Asian Earth Sciences 18, 453-469.

Lin, Chengkun, 1989. A study on the source and quantity of sediment at the Yangtse River estuary. Acta Geographica Sinica 44 (1), 22-32 (in Chinese).

Ministry of Geology, 1991. Regional geology of Sichuan Province. Ministry of Geology, People's Republic of China. Geological Memoirs Series 1 (23).

Osborne, A., 1998. Economic and ecological interactions in the lower Yangtse region under the Qing. In: Elvin, Mark, Liu, Ts'ui-jung (Eds.), Sediments of Time: Environment and Society in Chinese History. Cambridge University Press, pp. 203-234.

Porter, S.C., 2001. Chinese loess record of monsoon climate during the last glacial-interglacial cycle. Earth-Science Reviews 54, $115-128$.

Selby, M.J., 1993. Hillslope Materials and Processes. Oxford University Press.

Shen, H., 1998. Material flux and land-and-ocean interactions in the Changjiang Yangtze estuary. In: Saito, Y., Ikehara, K., Katayama, H. (Eds.), Proceedings of an International Workshop on Sediment Transport and Storage in Coastal Sea-Ocean System. Geological Survey of Japan, Tsukuba, pp. 1-7.

Stone, J.O., 2000. Air pressure and cosmogenic isotope production. Journal of Geophysical Research 105, 23753-23759, doi:10.1029/ 2000JB900181.

Sun, X., Song, C., Wang, F., Sun, M., 1997. Vegetation history of the Loess Plateau of China during the last 100,000 years based on pollen data. Quaternary International 37, 25-36.

Sun, X., Li, X., Lu, Y., Chen, X., 2000. The vegetation and climate at the last glaciation on the emerged continental shelf of the South China Sea. Palaeogeography, Palaeoclimatology, Palaeoecology $160,301-316$.
Vermeer, E., 1998. Population and ecology along the frontier in Qing China. In: Elvin, Mark, Liu, Ts'ui-jung (Eds.), Sediments of Time: Environment and Society in Chinese History. Cambridge University Press, pp. 235-279.

Wang, L., Chen, X., Chu, T., 1997. A contrast analysis on the loads character of the Changjiang River and Yellow River. Geographical Research 16 (4), 71-79 (in Chinese).

Xiao, J.L., An, Z.S., Liu, T.S., Inouchi, Y., Kumai, H., Yoshikawa, S., Kondo, Y., 1999. East Asian monsoon variation during the last 130,000 years; evidence from the Loess Plateau of central China and Lake Biwa of Japan. Quaternary Science Reviews 18, $147-157$.

Xue, C., 1993. Historical changes in the Yellow River delta, China. Marine Geology 113, 321-329.

Yang, S., Li, C., 1999. The element composition of Chang Jiang and Huang $\mathrm{He}$ sediments and the geological background. Marine Geology \& Quaternary Geology 19 (2), 19-25 (in Chinese).

Yi, S., Saito, Y., Zhou, Q., Wang, P., 2003. Vegetation and climate changes in the Chang Jiang (Yangtse River) delta, China, during the past 13,000 years inferred from pollen records. Quaternary Science Reviews 22, 1501-1519.

YWCC, 2001. Yangtse Water Control Committee of the Ministry of Water Control (eds.), Yangtse River Flood Defence Atlas, pp. 50-53 (in Chinese).

Zhang, C., Zhang, S., Wang, L., Wang, L., 1998. Geochemistry of metals in sediments from Chang Jiang and Huang He and their comparison. Acta Geographica Sinica 53 (4), 314-322 (in Chinese).

Zhang, P.Z., Molnar, P., Downs, W.R., 2001. Increased sedimentation rates and grain sizes 2-4 Myr ago due to the influence of climate change on erosion rates. Nature 410, 891-897.

Zhao, Y., Yan, M., 1992. Huang He, Chang Jiang and shallow seas: chemical element abundances. In: Zhao, Yiyang (Ed.), The Geochemistry of Sediments in Shallow China Seas, pp. 1202-1204 (in Chinese). 